\title{
The Politics of Pain in Immigration Detention ${ }^{1}$
}

\begin{abstract}
In this paper I draw on qualitative material from the first complete data set of the 'Measure of the quality of life in detention' (MQLD) survey in the UK to explore common causes of distress in immigration removal centres and to reflect on their implication for understanding and challenging these sites. While similarities between immigration detention centres and prisons make it tempting to place the testimonies from people in detention within the framework of the 'pains of imprisonment', I propose an alternative reading of these first-hand accounts. Rather than approaching them as sociological statements of suffering, caused by the loss of liberty, I interpret them as political statements which, in turn, demand a political response. Immigration Removal centres, these people assert, are fundamentally at odds with key values of a liberal democracy. Those detained within them are not considered to be equal members of a shared community of value; rather, their incarceration in detention centres marks them out symbolically but also, as the testimonies in this piece make clear, quite practically, as outsiders to these ideas. The pain people describe illuminates the need for a new politics of detention.
\end{abstract}

KEY WORDS:

Immigration detention; pains of imprisonment; distress; politics; liberal democracy

\section{INTRODUCTION}

As far as I am concerned the centre should be shut down, or change the policy in which the system is managed. [...] since I have been here my state of mind keeps deteriorating mentally I am losing my bearing, psychological am not the same no more. It's a system designed to torture and break people down both physically, mentally, emotionally and psychologically. (Abayomi², Brook House, no nationality given, $\mathrm{BH}$ 55)

In this paper, I draw on material from the Measure of the Quality of Life in Detention survey that was administered from July to September 2019 across all the UK immigration removal centres (IRCs) to explore how women and men cope with their incarceration and some of the

\footnotetext{
${ }^{1}$ I would like to thank the women and men who contributed to this research and Alice Gerlach with whom I collaborated on the wider research project. In that work we were assisted by Dominic Aitken, Francesca Esposito, Samuel Singler, and Elspeth Windsor in administering the survey. Elspeth further helped with data transcription and with identifying themes. Thanks also to Vanessa Barker and Samuel Singler who offered helpful comments on an earlier version of this paper which helped to deepen its engagement with political theory. I delivered rafts of this paper at the University of Alberta Centre for Criminological Research conference on 'Prisons and Punishment' on November 19, 2020 and at the Border Criminologies' 'Landscapes of Border Control and Immigration Detention' Conference on 24 May 2021. Thank you to the conference participants for your comments. The fieldwork for this project was funded by the Social Sciences Division at the University of Oxford.

${ }^{2}$ Not his real name. All of those I quote have been given pseudonyms.
} 
causes of their distress. Many of the problems survey respondents raise are familiar; in response to closed and open-ended questions people describe substandard food, poor medical care, a lack of meaningful activities, and low levels of trust in fellow detainees or staff. In criminological terms, we would normally conceive these kinds of matters as the 'pains of detention'. However, as I will argue, there are some important reasons to be wary of adopting this terminology, not least because of the way it maintains scholarly focus on the interiority of sites of confinement and on the specific individual stories, rather than on their relationship to and position within a wider network of social relations, politics, and the law. Instead, I suggest, different, and more radical, lines of inquiry and action open if we understand people's pain in political terms.

The suffering people report does not spring solely from the deprivations of life behind bars, nor can the problems they raise be resolved within the walls of the establishment. Instead, their words depict an institution that is fundamentally at odds with key promises of liberal democracy. For those confined, detention seems arbitrary and unrestrained by due process or legal certainty. The state is vindictive and capricious. Inadequate health care and substandard living conditions in the shadow of deportation communicate their exclusion from a community of value as well as of rights (Anderson, 2013).

When viewed in these terms, the 'pains of immigration detention' do not spring from the centres themselves, and thus do not fit within sociological traditions of study that have marked out so much of prison studies since Gresham Sykes (Sykes, 1958; Crewe, 2011). Rather, the problems I describe below raise fundamental (philosophical and political) questions about the ethics and legitimacy of border control in liberal democracies like the UK (Cole, 2000; Benhabib, 2004; Carens, 2008; Ellermann, 2010; Bauböck 2020; Hayter, 2004; Wellman and Cole, 2011). In so doing, they demonstrate the relevance of empirical research for normative debate (Longo, 2018; Longo and Zacka, 2019; Herzog and Zacka, 2019).

The paper proceeds as follows: First I sketch the current UK immigration detention system and some of the ways in which criminologists have approached similar institutions elsewhere. Then I turn to the survey methodology used to gather and organise the testimonies I cite. The bulk of the paper reflects on the implications of common issues identified by people in detention for our understanding of the role and nature of immigration detention in liberal democracy. Specifically, I assess claims about access to justice, inadequate medical care, and the impact of detention on people's families and their sense of self, as political statements that have a far wider implication than the nature of the specific institutions in which people are held. In conclusion, I argue that the pain people in detention recount illuminates the need for a new politics, which is angled towards abolition (Hayter, 2004), not just because we feel compassion for these specific individuals, but because suffering (always) demands redress (Shklar, 1982).

\section{OVERVIEW: THE PRISONIZATION AND PAINS OF DETENTION}

The UK locks up foreign national citizens in immigration removal centres (IRCs) for the purpose of their deportation, removal, or identification. The system is wholly contracted out by the Home Office to a small number of private sector security firms and the prison service. Many IRCs are either former prisons or have been built to prison security standards. Some 
people in detention have previously served a criminal sentence and many officers and senior managers have worked in the prison service. Notwithstanding all these connections to the criminal justice system, immigration detention is a purely administrative form of custody; nobody is serving a sentence and these places are not governed by the same rules of expectations about due process nor are they subject to the same level or kind of judicial oversight. In the UK, other than for pregnant women and families, there is no statutory upper time limit to the period for which someone can be held under immigration act powers.

The number of people detained in the UK under Immigration Act powers has been shrinking since 2016, in response to a series of critical independent reviews and court challenges to the incarceration and deportation of specific groups. From concerns over the treatment of 'vulnerable people' (Shaw, 2016; 2018), to outrage over staff brutality (BBC, 2017) and the wrongful deportations of the so-called Windrush generation (Gentleman, 2019), and notwithstanding widespread anti-migrant sentiment that predominated in the debates over exiting the European Union, the legitimacy of detention in Britain has been increasingly drawn into question.

The Covid-19 pandemic has, in some ways, reinforced the declining reliance on this form of custody as the government responded to the 2020 public health crisis by releasing the majority of those detained in IRCs, even as the sum of people held in prison under immigration act powers remained unaffected (AVID, 2020; Home Office, 2020). At year end 2020, for example, the numbers in removal centres had been hovering around 700 since June 2020, down from 1800 before the pandemic hit (Home Office, 2020). The peak of the detention estate occurred over six years ago, in 2014, at about 3500 (Home Office, 2020).

Before the pandemic, the UK detained people who had overstayed their visas, women and men whose asylum claims had been rejected, people who had violated the terms of their visa, or perhaps had never had one as they had arrived in the country in the back of a lorry, and foreign nationals who had served a prison term. Since March 2020, however, the population in IRCs has narrowed to two primary groups: ex-prisoners and asylum seekers who have travelled to the UK on small boats from the shores of Northern France. In the former, we see clearly how these institutions of administrative custody effectively act as an additional punishment for those born elsewhere. In the latter, we bear witness to how these sites are constantly reactive to contemporary politics of border control.

Although immigration detainees are not serving a sentence, those who come from prison may not fully appreciate the distinction between the institution in which they are placed for immigration matters and that from which they have been sent. Both are built securely and are ringed by high fences, topped with razor wire. In both they are placed in a shared cell and within both they are managed, helped, controlled, and restrained by uniformed officers who carry keys. Given these structural and policy overlaps, versions of which exist in most detention systems around the world, it is not surprising that criminologists have turned to the 'pains of imprisonment' framework to understand everyday life in these places. People in detention, these scholars point out, endure all the pains that Gresham Sykes (1958) identified so long ago, alongside a series of additional burdens (see, for example, Longazel et al, 2016). 
For Sykes, prison life was shaped by five specific deprivations. Prisoners lost their liberty, safety, and autonomy, as well as their access to heterosexual relationships, and goods and services. Over time, criminologists have added to this original list by referring to the 'depth, weight and tightness' of contemporary prison life that flows from sentence management and the work of prison psychologists (Crewe, 2011) and by distinguishing between women and men's experiences of long-term prison sentences (Crewe et al, 2017). Others have identified new forms of deprivation altogether, including that of 'certitude' for foreign national prisoners who face deportation as a result of their criminal conviction (Warr, 2016; Ugelvik and Damsa, 2018).

This approach to custody has influenced the study of immigration detention. In the US, for example, Jamie Longazel and colleagues argue that those in 'immigrant imprisonment' suffer four additional pains: 'containment', 'exploitation', 'coercion', and 'legal violence' (Longazel et al, 2016). In Norway, Liridona Gashi and her co-authors focus on the difficulties caused both by the uncertain temporal frame of border control and by the tedium of immigration detention centres which offer their inhabitants so little to do to pass the time (Gashi et al, 2019). While in Australia, Michelle Peterie (2018) claims that Sykes' categories illuminate life in Australia's offshore detention centres, especially when combined with accounts that have paid attention to gender differences (Walklate and Worrall, 2000), age (Cox, 2011), and the particular burdens associated with the deprivation of certitude (Crewe, 2011).

Many of these findings resonate with my research. As I will show below, women and men, wherever they are located, certainly struggle to cope with their confinement. Their levels of distress are high. However, like Kevin Haggerty and Sandra Bucerius (2020: 10), I have some reservations "about the continuing political or analytical utility of the concept [of the pains of imprisonment]." It is not just that the field of study has become "an uncoordinated aggregation of pains" which "risks becoming a dull chorus that cumulatively stresses that prison [or a detention centre] is a consistently wretched place, both for inmates and a coterie of other individuals" (Haggerty and Bucerius, 2020: 10), but that, as Haggerty and Bucerius point out, scholars seem more interested in "identification and typification" of pain, rather than in "outlining a pragmatic program for how these pains might be alleviated" (Haggerty and Bucerius, 2020: 11). As more categories and kinds of pain and deprivation are identified, there has not been a concomitant rise in suggestions of how to respond to them.

While Haggerty and Bucerius advocate more active engagement with the public to build greater sympathy and understanding for the plight of those behind bars, I worry that the public and politicians remain either broadly indifferent to those within, or perfectly content for them to suffer, at least a little. In terms of immigration detention specifically, while the UK government has sought, since 2016, to divert some of those people who are considered to be most vulnerable to adverse mental health outcomes in detention to non-custodial alternatives, via the 'Adults at Risk' policy (Home Office, 2019), concerns over vulnerability and suffering have not led to the dismantling of the detention system. Rather, such attention to vulnerability has allowed the government and its private sector partners have developed systems of selection and monitoring of those at risk. Similarly, even as the numbers detained during the pandemic dwindled, the Home Office kept most of the IRCs open, maintaining expensive contracts for unused beds and infrastructure. In 2021, as the pandemic began to 
ease, they announced plans to build a new detention centre for women and, quietly, reopened a facility that had been temporarily shut.

Given the enduring attachment of the state to custody, I suggest that the sociological frame of analysis with its close attention to life within the four walls of a custodial institution needs replacing, or at least refreshing, with one more squarely oriented outwards towards the community and the state. In taking this approach I draw on debates within political theory and about the purpose of sociological critique (Herzog and Zacka, 2017; Boltanski, 2017). ${ }^{3}$ To start this conversation, I consider first-hand accounts of the pains of detention as political claims. What pathways do these statements illuminate? And what forms of redress might they demand? Before we turn to such matters, I offer some detail about the methods used to gather the qualitative material used in this paper.

\section{THE QUALITY OF LIFE IN DETENTION: A METHODOLOGICAL NOTE}

The testimonies I cite below are all drawn from comments written on the Measure of the Quality of Life in Detention (MQLD) survey by people in detention. I designed and administered the first version of the survey in 2010 in the now-closed Campsfield House Immigration Removal Centre, near Oxford. Like the Measure of the Quality of Prison Life (MQPL) developed by Alison Liebling (Liebling et al, 2011), on which it is modelled, the MQLD draws on extensive and ongoing research inside immigration removal centres in the UK. It is, in other words, a living document. Findings from it have been produced in various publications and have informed policy and academic scholarship (see for example, Bosworth, 2013; Shaw 2016; Bosworth, 2014). In 2019, Alice Gerlach and I significantly reshaped the design and methodology of the MQLD to allow it to be administered more swiftly and efficiently. Together, working with a team of researchers we administered it in each of the UK's Immigration removal centres over a three-month period from July - September 2019. Since then, COVID-19 has prevented research inside detention centres.

The survey is distributed in the following manner: the researchers attempt to approach every individual in each centre, in person, to offer them a survey over a two-day period. ${ }^{4}$ In this round, 459 men and women ${ }^{5}$ completed and returned the survey, amounting to $33 \%$ of the population at the time of the visits. Despite the uniform strategy we deployed across all institutions, the return rate varied among them from a low of $21 \%$ in Morton Hall to $41 \%$ in Yarl's Wood and Dungavel. Surveys were available in English, Albanian, Arabic, Bengali, Chinese, Polish, Russian, Urdu and Vietnamese. Ninety-two people chose to fill their survey in a language other than English. ${ }^{6}$ More information about the survey design and its findings

\footnotetext{
${ }^{3}$ I am grateful to Matthew Gibney and lan Loader for conversations about these issues.

${ }^{4}$ To facilitate our own movement around the centre without needing assistance from custodial staff, some members of the team are issued with keys. This practice is much more common in UK-based custodial research than in the US, and while it clearly raises ethical and practical questions, these are outside the remit of the paper (for more on this issue see Bosworth, 2014).

${ }^{5}$ The survey includes questions about identity and these were the only categories people selected.

${ }^{6}$ In Yarl's Wood and Colnbrook a research assistant was also able to assist Portuguese and Italian speakers to fill the survey through translation. We did not have translators for other languages, and nor did we receive many requests for other languages. However, the lower response rate in Morton Hall appeared to be the result of one large group of Albanians, who had low levels of literacy and of trust. Even though the survey has been translated into Albanian many were unwilling to complete it, while others who wished to do so, were
} 
can be found in the most recent report and in related articles (Bosworth and Gerlach, 2020; Bosworth and Kellezi, 2013). IRCs are particularly difficult sites to access, and in which to gain trust. These issues are well-documented in the interdisciplinary field of study and do not need rehearsing here (see, for example, Bosworth and Kellezi, 2017; Aitken, 2018).

Like the MQPL, the MQLD measures detainees' perceptions of the quality of their life in the custodial institution in which they are currently residing through questions on safety, fairness, communication, and staff/detainee relations. It includes demographic questions, and asks respondents about their immigration case, their access to legal assistance, and their sense of their mental and physical health. Since 2019, the survey has included a coping scale to measure distress. This measure is calculated by adding the scores of all individual answers to 14 questions to create a coping scale 'score'. The lowest possible score on the measure is 0 and the highest 42 . Higher scores on the scale suggest individuals are coping less well than those who achieve lower scores. The mean score on the coping scale across all removal centres was 28 . This positive skew indicates that most individuals across all institutions report high levels of distress.

In addition to the closed-ended questions that make up the majority of the questionnaire, participants are invited to write in comments on the final page of the survey where they are asked 'is there anything else you' $d$ like to tell us'. People also sometimes annotate other parts of the survey to expand on their tick-box responses. The research team checks these sections of the survey before leaving the establishment each day, to identify any potential safeguarding matters.

After completion, the surveys were individually scanned to extract the quantitative data. This material formed the basis of a published report which was shared with the Home Office and the private contractors and made publicly available on the Border Criminologies website (https://bordercriminologies.law.ox.ac.uk; Bosworth and Gerlach, 2020). Qualitative data that was written onto 277 of the surveys (60\%) was subsequently transcribed fully by a member of the research team and organised under a series of broad themes that emerged from the accounts. The coding scheme grouped comments about safety, food, health care, and activities within the centres well as statements on access to legal assistance, and people's experiences of the wider immigration system, and their feelings of exploitation, dehumanisation and human rights. Following Longo and others, I use these themes interpretively in the sections below to reflect on the possibility of generating theory from empirical work (Longo, 2018; Longo and Zacka, 2020). While I have edited some quotes for clarity and length, for the most part, I have kept people's original spelling and punctuation. I have also given all the participants pseudonyms. Where possible I cite the nationality people self-reported on the survey, to give a sense of the diverse pool of respondents. I also identify the institution in which they were based.

IMMIGRATION DETENTION AND THE LIMITS OF LIBERAL DEMOCRACY

unable. We did not have an Albanian translator and so could not assist them. This aspect of doing research in IRCs reveals starkly how language matters not only in border control nut in our bid to understand it (see Aliverti and Seoighe, 2017 for a discussion of the importance of translation work in criminal courts). 
In her 1998 re-reading of the work of German jurist, philosopher, and Nazi, Carl Schmitt, Chantal Mouffe critiques his argument about the incompatibility between liberalism and democracy. Known to criminologists largely through scholarship on enemy criminal law (see, for example, Krasmann, 2003 and Zedner, 2013), Schmitt wrote extensively on what he perceived to be the limitations of liberalism and democracy. Unsurprisingly, given his eventual support of the Holocaust, Schmitt believed that heterogeneity was anathema to democracy, and that the belief in 'humanity' and other transcendent notions inherent in liberalism, were dangerous and ill advised (Triadafilopoulos, 2011).

While rejecting Schmitt's bleak and ultimately violent conclusions, Mouffe nonetheless agrees that there is a tension between liberalism and democracy, pointing out that in contrast to liberalism's emphasis on humanity and shared rights, democracy always entails relations of inclusion and exclusion; she refers to this move as the 'moment of closure' that is required for constituting a democratic political community. Not everyone can be a member. Because the tension between these two issues can never be fully eradicated, Mouffe argues, social and political analysis should focus on the processes through which the political community is formed.

In the written comments on the surveys we catch a glimpse of these processes and what it feels like to be excluded from liberal democracy. We see, in other words, the political nature of immigration detention, not as an artefact of politics, but as a site where the limits of liberalism and democracy are made concrete (Benhabib, 2004).

The vast majority of those who took the time to add free-text comments written onto the survey complained about their experience of immigration detention. Only seven of the 277 who wrote onto the survey, offered any form of praise. Of these, two concerned the assistance provided by an NGO, with the remaining five ranging from Jakub in Harmondsworth who noted briefly "It's ok (-)"( $\mathrm{H}$ 83, Poland), to Christina in Yarl's Wood who claimed that the "Facilities are good and the officers are all supportive to own needs," before demanding "but if possible to abolish this detention centre because we are mentally tortured here." (YW 22, Philippines) All other respondents offered more or less expansive versions of Blerin's view from Harmondsworth: "Everything is sheet [shit] here. Nothing good." (H 22, Albania)

Many of those who wrote comments onto the survey complained about healthcare provision, and, in particular, the lack of mental health care support. Women and men were also unhappy about the food, regularly referring to it as inedible and sometimes spoiled or uncooked. Some simply did not have enough to eat.

Across all the centres too people raised concerns about poor hygiene and a general lack of cleanliness. In Harmondsworth men complained about bedbugs and in Colnbrook they had mice. Those in Morton Hall reported a problem with rats. Everywhere people criticized the lack of fresh air and access to outdoor spaces, insufficient activities and paid work, and the difficulties they faced in communicating with staff and with their immigration case workers.

In this lengthy note, Abdul, brought these issues together. 
I am asthma attack pation [sic]. I have breathing difficulties, anxiety, agitation, memory loss, anti depression, suicidal thoughts, loss of appetite [...]. Extreamly stomack pain..., wait loss..I cant eat food here. My stomack is burning when l eat food here.... Sometimes they serve rotten bread. I cant leave the environment. I need more care and medication which is I can get from my communities people. (Abdul, Sierra Leone, Brook House, BH 63)

Ade, in a different centre, wrote much the same thing, rather more bluntly:

Everything is shit in here no lie. No communication, everything is on permanent hold. No fan in cells and summer time is really hard. We can find it difficult to breath in the cells. The foods are of low quality. We basically eating rice every other day...The beds are not comfortable, hella bed bugs... The winds stink often. Detainee workers are not paid good money. (Ade, IRC Harmondsworth, Nigeria, H 27)

At first glance, complaints about safety, food, and healthcare fit comfortably within the traditional 'pains of imprisonment' approach as examples of the kinds of deprivations associated with the loss of liberty, security, autonomy, and goods and services. Certainly, there are some practical issues that service providers could improve in terms of the quality and quantity of the regime. However, the survey respondents were not simply concerned with the conditions of their confinement, instead, they depict a world of arbitrary state power, unrestrained by due process legal protections, in which poor medical care and indifferent staff deny their essential value as human beings. When seen in these, political terms, the implications of their testimonies are far more devastating and urgent.

The women and men who completed the survey were fearful. In their testimonies we see the affective impact of the overlap between border control and criminal justice, as 'crimmigration' practices (Stumpf, 2006) internally divide the detained community from itself. In Yarl's Wood, for example, Lisa worried: "we are mixed with all kind of persons even prisoners we don't even know if they are dangerous." (YW 38, no nationality recorded). Likewise, in Brook House, Ekon noted that "been in a detention centre with criminals do not make me feel safe" (BH 24, Nigeria).

Many were not just afraid of the other people with whom they were confined, but they were traumatised by the design of the institution itself. Ama, who was held in Yarl's Wood, sought to explain:

"Legal department and the whole centre [feel unsafe]. Being called to the legal department tortures most detainees in the centre. [It] is very hard waking up every morning and constantly waiting or anxiously waiting to be called, name announce loudly or receive a text to come to Legal (tickets, refusals etc are given at Legal)." (YW 46, Ghana)

The reason for such fear was simple, Lukasz -- who was placed in Harmondsworth after serving a prison sentence -- wrote:

PEOPLE A TERIFAT WHAT IS HAPPON TO THEM NEXT. 2 DAYS AGO ANOTHER GUY CUT HIM SELF BECAUSE HOME OFFICE WANT TO DEPORT HIM WHEN HE LIV HERE 
WITH HIS FAMILY AND 3 CHILDREN FOR LAST 15 YEARS. PEOPLE TRYING HANGING THEM SELF IS WHAT THE SITUATION IN HARMONDSWORTH IRC." (capitals and (phonetic) spelling in original, H 37 Polish)

In these quotes, we catch a glimpse of the workings of the immigration control system, and, specifically, of the impact of its legal uncertainties. These uncertainties are heightened in the legal corridor where people meet immigration officers from the Home Office. These government employees hand out removal directions, deliver news about asylum claims and immigration bail, and pass information between the external immigration case owners (who decide people's cases) and those in detention (who petition them). The legal corridor is also where detainees may meet with a legal representative. Here too they take part in online bail hearings.

When people are called to the legal corridor, they will not know if they are about to learn of their temporary release or of plans for their expulsion. This uncertainty, these testimonies make clear, is, for many, unbearable. It is more than just a pain of detention, however. Instead, the fear people experience when called to the legal corridor, springs from the operation of border control itself in which at least half of those confined are eventually released, and nobody can know the outcome of their time in custody. Under these uncertain conditions, detention not only feels arbitrary and frightening but it fundamentally alters people's sense of themselves, their relationship to the wider society and their view of it. "The country is not for man or woman. It is for UFO", one man wrote poetically ( $24 \mathrm{H}$, Jamaica).

The uncertainty of these sites is hard to bear or as Ejo in Yarl's Wood made clear, to explain:

Yarls Wood Removal Centre is entirely a different world built on this planet earth whereby you go through things you've never wanted to wish for yourself ie bitterness, trauma, depression, frustration, useless, empty and feel like life is not worth living. Yarls Wood removal centre and the entire Home Office and the court do not give us FAIR TRIAL, none of our cases are being considered! Seems like anything or case we tell them is rather used against us by refusing them. Some of our cases are refused with NO RIGHT TO APPEAL. Some of the judges [...] is frustrating people with not granting bail at the expense of your freedom because she works with the Home Office (sources are TRUE). We are facing a lot of trials and tribulations here in Yarls Wood.

(YW 3, Ghana)

In Brook House, Orhan identifies another version of the problem some people face:

I've been held captive here for the last five days and the upcoming four days will be the same even if I am telling everyone that I want to go back to Turkey. It took me solid five days to get an answer, and no officer was then permitted to intervene in such cases. (BH 58, Turkey)

Matters for many were compounded by inadequate health care. In Yarl's Wood, Gina complained indignantly, in a familiar criticism, "Healthcare only give paracetamol for all problems!" (YW, 15, El Salvador). While in Harmondsworth Krish wrote, 
This centre is not good, especially medical services. Doctors not look after us detainee. But Home Office claims these is all services providing perfectly. But I hardly getting appointment with GP while I am very depressed and can't sleep all night. I spoke to wing officers many times about my concerns but they never helped me once. (H 15, India).

As with the barriers to justice, these kinds of quotes paint a picture of an institution in which those confined struggle to access the help they need.

Some, like Bahadur, raised allegations about inadequate provision for torture survivors. "I have been a victim of torture in my country Uzbekistan", he wrote in Morton Hall. "I have trouble sleeping at night suffering from PTSD. And I'm not receiving the correct help for me to be able to deal with the nightmare I am suffering from." (MH 12). Hundreds of miles further South, in IRC Harmondsworth adjacent to Heathrow Terminal Five, Faizan from Pakistan, described a system which compounded the damage caused by his prior experience of state violence. Thwarted by bureaucratic practices and unfeeling staff, Faizan struggled to access the legal protections he was due. Like Bahadur in Morton Hall, Faizan's testimony demonstrates the enduring impact of prior trauma on custody, as well as the way in which internal processes within IRCs exacerbate the pain caused by these earlier harms.

I've been a torture victim and confinement makes me well paranoid ... I applied for Rule 35 so doctor could certify me as rape and torture victim and say detention further deteriorates my mental health but after 2 weeks the day I was supposed to see doctor they transferred me here and now have to wait another 6 weeks. In those eight weeks I probably would have committed suicide. When I asked here to book my Rule 35 appointment but the lady Indian officer was being a bitch she said, and I quote 'I'm not doing appointment cos you people think you can do rule 35 and walk free. This is not happening.' And she harassed me for another 15 minutes before booking doctor's appointment when her job is to book and not question. (H 20, Pakistan)

In the facility next door, at Colnbrook, another man offered a perspective on the same issue. "This centre does not care about your health," John complained. The problems he faced, John made clear, however, were not simply a result of the indifferent with which he was treated, but rather sprang from purpose of detention itself, and the way in which it trumped all other concerns. "I went to see healthcare," he wrote. "I told the nurse about some issues that I have. The first question she asked was, are you going to be deported? I did not know that healthcare department is working with immigration." (CB 59, no nationality listed).

In these accounts, people in different institutions describe a system in which the internal workings of the detention centres are shaped by the external purpose of border control: expulsion. It is not just that those detained find it difficult to resolve their immigration case, or to cope with their loss of liberty, but that their daily life inside is both shaped by external factors and limits their ability to resolve them. Lawyers, who might help them challenge their immigration case, are hard, if not impossible, to access. Nurses and custodial staff in these institutions are actually border guards. 
These factors, spread beyond these institutions, the testimonies make clear, as people are separated from their friends and families. "Most of all been in detention is taking a toll on my private life with my girlfriend and most of all my family eg: my mother and younger brother", Bahadur wrote from Morton Hall (MH 12). The threat of deportation is extremely painful. "I been 7 month in this centre," Ranbir wrote from "I been thinking about my kids all the time I am so upset on this palace. I have mintel health eshu but noboday help me I feel low all the time PLZ HELP ME IF YOU CAN I DON'T SPEK ENGLISH." (97 H, India). In the same centre, Aleksander stated "ANOTHER GAY [GUY] CUT HIM SELF BECAUSE HOME OFFICE WANT TO DEPORT HIM WHEN HE LIV HER WITH HIS FAMILY AND 3 CHILDREN FOR LAST 15 YEARS" (37 $\mathrm{H}$, Polish). In the facility next door, in Colnbrook, Miguel lamented, "I am so lonely. I want my kids back. My depression is extreme. My health is deteriorating." (CB 30, Brazil).

These quotes from people in detention illuminate the lived experience of the kind of 'abnormal justice' that border criminologists have identified as a key effect of the growing intersections between immigration control and criminal justice. Like 'regular' (or indeed criminal) justice, these practices rest on and articulate membership (Barker, 2013; Franko Aas, 2014; Aliverti, 2016). In marking out who belongs and who is unwelcome, border control communicates important political lessons about the limits of liberal democracy.

On the one hand, as others have observed, certain foreigners are easy to exclude including those without immigration status, or who have committed an offence. Yet others, (and indeed some undocumented people and former offenders), are harder to deny (Honig, 2001). Liberal democracies may be bounded nation states, but they are founded on a belief that those from elsewhere who follow specific procedures may join the polity. Liberal democracies likewise recognise some (legal and ethical) obligations to those who have may have lived among them for many years. Citizenship is not the only route to rights, nor does it always protect them (Gibney, 2013).

Immigration detention centres make concrete many of these conceptual tensions. In so doing, like the criminal justice institutions studied by Amy Lerman and Vesla Weaver in the US, these carceral sites are usefully considered as political institutions "through which we formalize and make real the character of democracy" (Lerman and Weaver, 2014: 60). When considered in this light, the implications of the barriers Ama faced in Yarl's Wood accessing due process protections and the rule of law, are wider than her personal disappointment and distress. Instead, the opaqueness of the legal system she describes and the lack of checks and balances which she encounters in detention, fall far short of the legal protections liberal democracies promise.

Similarly troubling matters can be found in other testimonies. In Orhan's reference to himself as a 'captive,' for example, the British state appears as kidnapper. What form of custody is this, his words demand?

In Tinsley House, a young man still in his teens, Farzaad, threatens suicide, not just because of the poor quality of his experience of confinement but for what awaits him upon return to Afghanistan. His anguished words, in turn, raise profound questions about state culpability and complicity in safeguarding his most basic right, to life: "Who is gonna be responsible for that?" he wants to know. "I am a young boy [only 19 years old.] I don't know why the Home 
Office playing with my life cuz the Home Office know better than me what's going on in Afghanistan and he keep me in this centre. I have problem.' (TH 10, Afghanistan).

While finally, in Colnbrook, Mohammed picks up the question of human rights asserting in terms familiar to critical academic scholarship and first-hand accounts alike, that "You can see and experience everything here except human right and law" (CB 63). Yet, as he goes on, the difficulty he faces is not merely one of barriers to rights and legal protections. He is not in a lawless place. Rather, he writes, "We are slave and immigration acting like our Lord and this facility is all about businuses to making money it is very difficult and no possible some time to get release on bail." (CB 63)

By connecting all these elements - rights, race, and privatisation -- Mohammed and the rest of those who wrote on the survey, do far more than describe a set of deprivations caused by a loss of liberty. Instead, in rudimentary English, they describe the workings and effects of an authoritarian, racial, political system.

The world these people describe in which they are kidnapped and made slaves, in which their family ties are sundered and their human rights denied, raises uncomfortable questions about promises of equality and recognition that are central to liberal democracy in narrow, legal terms and in broader, moral claims (Silverman, 2014; Bertram, 2018). In so doing, their testimonies connect to other troubling dynamics and events around the world. For in an historical era when we have seen the authoritarianism of Orbán in Hungary, the white supremacy of Trump in the U.S. and the cronyism of the Conservative government in the UK flourish, we have numerous examples beyond the walls of detention of how key liberal values and institutions across numerous democracies are being corrupted.

Promises of tough border control have played a prominent role in all these campaigns (Vigneswaran, 2020). Over the same period, we have seen in the international Black Lives Matter movement, how deep anguish over the failed promises of equality in the law can bring people together to reaffirm a belief in the importance of these values and their relevance for us all. While calls to defund the police may yet remain unanswered, this social movement has inspired an overdue global discussion about access to justice and formal and substantive equality across liberal democracies. As criminal justice institutions and their wider impact on the kind of society in which we live come under greater scrutiny in these terms, the testimonies of those cited in this article suggest that immigration removal centres should as well.

\section{CONCLUSION: ON THE LIMITS OF PAIN AS A MODE OF EXPLANATION}

As the survey makes clear, and extensive research has shown, detention centres are replete with pain and suffering. Those who are confined within them, as well as many who work there too, are unhappy. Bureaucratic factors compound distress.

Despite this evidence, and notwithstanding extensive opposition to these institutions from a wide distribution of people across society, the government remains committed to immigration detention centres. These institutions are quite clearly a political choice. During 
the pandemic, the British government could have closed them all. But it did not. Compounding matters, these institutions and the practices associated with them appear to be broadly supported by the voting public. They are, in short, a popular political choice.

When considered in this light, the testimonies from those in detention invite us to reflect not only on the 'quality of life' behind bars, or the 'pains of detention' but on the wider implications or "civic learning" these political institutions provide (Lerman and Weaver, 2014: 91). As sites for foreigners that look like prisons, these institutions communicate important political lessons about membership of the nation state. The racialised make-up of those within, suggest the enduring nature of empire.

While it is difficult to be optimistic, particularly when the current British government is in the process of passing the new, and more restrictive Nationality and Borders Bill, pain of the kind reported by those in detention, need not be an inescapable result of the "moment of closure" of liberal democracies. Instead, it could form the basis for a new commitment to minimizing cruelty. If we take seriously the claim that pain is political, we can do more than argue that these border control practices fall short of some universal ideal that we value. Rather, the distress of the people recorded here can form the basis for keeping the boundaries of our democracies (and value systems) open.

In this final task, we see also the potential for developing normative theory from applied research. For, however hard they may find it to make their voices heard, those within these sites of custody are not silent, nor are they abject. They are agents, with ideas. Their pain illuminates solutions. A resident of the UK for 9 years before her detention in Yarl's Wood Immigration Removal Centre, Clara was clear and to the point: "This centre [and all the others] needs to be closed down as soon as possible. Because us immigrant are treated like animals without respect [...] We are human beings for God sake. We are all equal." (YW 36, no nationality recorded).

\section{References}

Abizadeh, A (2008) Democratic Theory and Border Coercion. No Right to Unilaterally Control Your Own Borders. Political Theory 36(1): 37-65.

Aitken, D (2020) Life and Death in Immigration Detention. In: Fili, A, Jahnsen S and Powell R (eds) Criminal Justice Research in an Era of Mass Mobility. Abingdon: Routledge.

Aliverti, A (2016) Doing Away with Decency? Foreigners, punishment and the liberal state. In: Eriksson, A (ed) Punishing the Other: The Social production of immorality revisited. Abingdon: Routledge. pp. $124-144$.

Aliverti, A and Seoighe, R (2017) Lost in Translation? Examining the Role of Court Interpreters in Cases Involving Foreign National Defendants in England and Wales. New Criminal Law Review 20(1): $130-156$. 
Anderson, B (2013) Us \& Them? The dangerous politics of immigration control. Oxford: Oxford University Press.

AVID (2020) We need to talk about detention in prison. London: AVID. Available at: http://www.aviddetention.org.uk/news-events/news/we-need-talk-about-detention-prison. Last Accessed: 16 November 2020.

Barker, V (2013) Membership Matters Most. In: Aas, K and Bosworth, M (eds) Borders of Punishment: Citizenship, Crime Control, and Social Exclusion. Oxford: Oxford University Press.

Barker, V (2007) The Politics of Pain: A Political Institutionalist Analysis of Crime Victims' Moral Protests. Law \& Society Review 41(3): $619-663$.

Bauböck, R (2020) A free movement paradox: denationalisation and deportation in mobile societies. Citizenship Studies 24(3): 389-403.

BBC (2017) Panorama: Undercover- Britain's immigration secrets. Available at: https://vimeo.com/242268669

Benhabib, S (2004) The Rights of Others: Aliens, Residents, and Citizens. Cambridge: Cambridge University Press.

Bertram, C (2018) Do States Have the Right to Exclude Immigrants? Cambridge, UK: Polity Press.

Bolstanski, L (2017) On Critique: A Sociology of Emancipation. Cambridge: Polity Press.

Bosworth, M (2014) Inside Immigration Detention. Oxford: Oxford University Press.

Bosworth, M, Franko, K, and Pickering, S (2018) 'Punishment, Globalization and Migration Control: "Get them the Hell out of Here. Punishment \& Society 20(1): $34-53$.

Bosworth, M and Gerlach, A (2020) Quality of Life in Detention: Results from MQLD questionnaire data collected in IRC Gatwick (Brook House and Tinsley House), IRC Heathrow (Colnbrook and Harmondsworth), Yarl's Wood IRC, Morton Hall IRC, and Dungavel IRC: July 4 - September 20, 2019. Oxford: Centre for Criminology.

Bosworth, M and Kellezi, B (2013) Developing a Measure of the Quality of Life in Detention. Prison Service Journal 205: 10 -15.

Canning, V (2019) Degradation by design: Women and Asylum in Northern Europe. Race \& Class 61: 46- 63.

Canning, V (2017) Gendered harm and structural violence in the British asylum system. Abingdon: Routledge. 
Carens, J H (2008) The Rights of Irregular Migrants. Ethics and International Affairs 22(2): 16386.

Chamberlen, A (2018) Embodying Punishment: Emotions, Identities and Lived Experiences in Women's Prisons. Oxford: Oxford University Press.

Cole, P (2000) Philosophies of Exclusion: Liberal Political Theory and Immigration. Edinburgh: Edinburgh University Press.

Cornelisse, G (2010) Immigration Detention and Human Rights. Rethinking Territorial Sovereignty. The Hague: Martinus Nijhoff Publishers.

Cox, A (2011) Doing the Programme or Doing Me? The Pains of Youth Imprisonment. Punishment \& Society 13(5): 592-610

Crewe, B (2011) Depth, Weight, Tightness: Revisiting the Pains of Imprisonment. Punishment \& Society 13(5), $509-529$.

Crewe, B. (2009) The Prisoner Society. Oxford: Oxford University Press.

Crewe, B, Hulley, S, and Wright, S (2017) The Gendered pains of life imprisonment. British Journal of Criminology 57(6): 1359 - 1378.

Detention Action (2016) Without Detention: Opportunities for Alternatives. London: Detention Action. Available at: https://detentionaction.org.uk/wpcontent/uploads/2018/08/Without-Detention.pdf. Last Accessed 18 November 2020.

Ellermann, A (2014) The Rule of Law and the Right to Stay: The Moral Claims of Undocumented Migrants. Politics \& Society 42(3): $293-308$.

Ellermann, A (2010) Undocumented Migrants and Resistance in the Liberal State. Politics \& Society 38(3): $408-429$.

Franko, K (2020) The Crimmigrant Other: Migration and Penal Power. Abingdon: Routledge.

Franko Aas, K (2014) Bordered Penality: Precarious membership and abnormal justice. Punishment \& Society 16(5): 520 - 541.

Gashi, L, Pederson, W, and Ugelvik, T (2019) The pains of detainment: Experience of time and coping strategies at immigration detention centres. Theoretical Criminology. Online First. doi:10.1177/1362480619855989

De Genova, N (2002) Migrant "illegality" and Deportability in Everyday Life. Annual Review of Anthropology 31: 419 - 447.

Gentleman, A (2019) The Windrush Betrayal: Exposing the Hostile Environment. London: Guardian Faber Publishing. 
Gibney, MJ (2011) The rights of non-citizens to membership. In: Sawyer, C and Blitz, B (eds) Statelessness in the European Union: Displaced, Undocumented, Unwanted. Cambridge: Cambridge University Press. pp. $41-68$.

Hancock, P, and Jewkes, Y (2011) Architectures of incarceration: The spatial pains of imprisonment. Punishment \& Society 13(5): $611-629$.

Haggerty, K, and Bucerius, S (2020) The proliferating pains of imprisonment. Incarceration. doi: $10.1177 / 2632666320936432$

Hayter, T (2004) Open borders: The case against immigration controls. Pluto Press, London.

Herzog, L, and Zacka, B (2017) Fieldwork in Political Theory: Five Arguments for an Ethnographic Sensibility. British Journal of Political Science 49(2): 763-84.

Home Office (2020) Immigration statistics data tables, year ending June 2020. Available at: https://www.gov.uk/government/statistical-data-sets/immigration-statistics-data-tablesyear-ending-june-2020\#detention. Last accessed 16 November 2020.

Home Office (2019) Adults at risk in immigration detention, version 5.0. London: HMSO. Available

https://assets.publishing.service.gov.uk/government/uploads/system/uploads/attachment data/file/919791/adults-at-risk-policy-v5.0ext.pdf. Last accessed: 16 November 2020.

Honig, B (2001) Democracy and the Foreigner. Princeton, NJ: Princeton University Press.

Kox, M, Boone, M, and Staring, R (2020) The pains of being unauthorized in the Netherlands. Punishment \& Society 22(4): $534-552$.

Krasmann, S (2007) The enemy on the border: Critique of a programme in favour of a preventive state. Punishment \& Society 9(3): 301-318.

Lerman, A, and Weaver, V (2010) Arresting Citizenship: The democratic consequences of American Crime Control. Chicago: Chicago University Press.

Liebling, A Hulley, S and Crewe, B (2011) Conceptualising and Measuring the Quality of Prison Life. In: Gadd, D, Karstedt, S, and Messner, S (eds) The Sage Handbook of Criminological Research Methods. London: Sage.

Longazel, J Berman, J and Fleury-Steiner, B (2016) The pains of immigrant imprisonment. Compass 10(11): $989-998$.

Longo, M (2018) The Politics of Borders: Sovereignty, Security and the Citizen after 9/11. Cambridge: Cambridge University Press. 
Longo, M and Zacka, B (2019) Political Theory in an Ethnographic Key. American Political Science Review 113(4): 1066 - 100.

Mehta, R (2016) Borders: A view from Nowhere. Criminology \& Criminal Justice 16(3): 286 300 .

Mouffe, C (1998) Carl Schmitt and the Paradox of Liberal Democracy. In: Dyzenhaus, D (ed) Law as Politics: Carl Schmitt's Critique of Liberalism. pp. 159 - 175.

Peterie, M (2018) Deprivation, Frustration and Trauma: Immigration Detention Centres as Prisons. Refugee Survey Quarterly 37: 279 - 306.

Philips, C (2010) The Multicultural Prison. Oxford: Oxford University Press.

Shaw, S (2016) Review into the Welfare in Detention of Vulnerable Persons: A Report to the Home Office by Stephen Shaw. London: HMSO, CM 9186.

Shaw, S (2018) Assessment of Government Progress in Implementing the Report on the Welfare in Detention of Vulnerable Persons: A Follow-Up Report to the Home Office by Stephen Shaw. Cm 9661. London: HMSO.

Shklar, J (1982) Putting Cruelty First. Daedalus 111(3): 17 - 27.

Silverman, SJ (2014) Detaining immigrants and asylum seekers: a normative introduction. Critical Review of International Social and Political Philosophy 17(5): 600-617

Sykes, G (1958) The Society of Captives. Princeton, NJ: Princeton University Press.

Triadafilopoulos, T (2011) Illiberal Means to Liberal Ends? Understanding Recent Immigrant Integration Policies in Europe. Journal of Ethnic and Migration Studies 37(6): 861-880.

Ugelvik, T and Damsa, D (2018) The Pains of Crimmigration Imprisonment: Perspectives from a Norwegian All-foreign prison. The British Journal of Criminology 58(5): 1025 - 1043.

Vigneswaran, D (2020) The Complex Sources of Immigration Control. International Migration Review 54(1): 262-288.

Walker, S and Worrall, A (2000). Life as a Woman: The Gendered Pains of Indeterminate Imprisonment. Prison Service Journal 132: 27-37.

Warr, J (2016) The Deprivation of Certitude, Legitimacy and Hope: Foreign National Prisoners and the Pains of Imprisonment. Criminology \& Criminal Justice 16(3): 301-18.

Wellman, CH and Cole, P (2011) Debating the Ethics of Immigration. Is there a Right to Exclude? Oxford: Oxford University Press. 
Zedner, L (2013) Is the Criminal Law only for Citizens: A Problem at the Borders of Punishment. In: Aas, K and Bosworth, M (eds) The Borders of Punishment. Oxford: Oxford University Press. pp. $40-57$. 